Brit. J. industr. Med., 1960, 17, 60

\title{
EXCRETION OF TRICHLOROETHYLENE METABOLITES IN HUMAN URINE
}

\author{
BY \\ B. SOUČEK and D. VLACHOVÁ \\ From the Institute of Industrial Hygiene and Occupational Diseases, Prague
}

(RECEIVED FOR PUBLICATION FEBRUARY 23, 1959)

Five healthy subjects were exposed to known concentrations of trichloroethylene (T.R.I.) for five hours. The amount retained was calculated. The excretion of the metabolites monochloroacetic acid (M.C.A.), trichloroacetic acid (T.C.A.), and trichloroethanol (T.C.E.) in the urine was measured over the next seven to 14 days. Metabolites excreted represented an average of $73 \%$ of the dose of T.R.I. retained (M.C.A. $4 \%$, T.C.A. $19 \%$, T.C.E. $50 \%$ ). The amount and speed of excretion of metabolites in one experiment was increased by giving glucose and insulin. The diurnal variation in the excretion of T.C.A. is emphasized.

After the vapour of T.R.I. has been inhaled the metabolites T.C.A., and M.C.A. are excreted in the urine. Trichloroacetic acid was first detected in canine and human urine by Barrett and Johnston (1939) and Barrett, Cunningham, and Johnston (1939), trichloroethanol was found in canine urine by Butler (1948) and in human urine by Souček and Vlachová (1954). These authors also found monochloroacetic acid to be excreted.

A number of quantitative studies of the formation of the metabolites of T.R.I. have been made. Most interest has been taken in trichloroacetic acid. The prolonged excretion (10 to 14 days) of T.C.A. even after a single exposure to T.R.I. is striking (Barrett et.al., 1939; Forssman, 1945; Forssman and Ahlmark, 1946; Souček and Pavelková, 1953). The excretion of the sodium salt of T.C.A. introduced into the organism is equally slow (Powell, 1945; Ahlmark and Forssman, 1949) and has not been satisfactorily explained. Fabre (1949) and Fabre and Truhaut (1952) assumed that it became linked to the red cells but experiments in vitro by Souček (1955) did not confirm this view although linkage to the plasma proteins was considered possible (Souček, 1954).

The gradual increase of the T.C.A. concentration in the plasma and urine for some time after the end of the exposure to T.R.I. is similarly unexplained. Ahlmark and Forssman $(1949,1951)$ found the excretion of T.C.A. began two to four hours after the beginning of exposure but Souček, Teisinger, and Pavelková (1952) showed that it could be detected within a few minutes. Thereafter it is agreed that the concentration of the T.C.A. in the urine rises to a maximum at 24 to 48 hours and subsequently decreases exponentially for a number of days.

The amount of T.C.A. formed from retained T.R.I. appears to vary with the species. In dogs the T.C.A. excreted accounts for 5-8\% of the T.R.I. (Barrett et al., 1939); in rats for $4 \%$ (Forssman and Holmquist, 1953); in rabbits for 0.5\% (Bartoníček and Souček, 1959). In man higher values have been found: 6-16\% (Ahlmark and Forssman, 1951); 7-27\% (Souček et al., 1952); $13 \%$ (Grandjean, Münchinger, Turrian, Haas, Knoepfel, and Rosenmund, 1955).

Trichloroethanol was shown by Butler (1949) to be eliminated in dogs mainly bound to glucuronic acid, and the amount excreted was three to four times that of T.C.A. The relationship of T.C.A. to T.C.E. has been found in man to be $1: 2$ to $1: 4$ (Souček and Vlachová, 1954); $1: 2$ to $1: 7$ (Teisinger, Stýblová, and Vlachová, 1955); $1: 0.5$ to $1: 5$ (Bardoděj and Krivucová, 1958).

In this paper we have investigated the quantitative relationships of the formation, and the course of elimination in the urine of all three trichloroethylene derivatives following inhalation of its vapour.

Experimental Methods

Seven experiments were carried out on three men and two women of an average age of 21 years, who previously had never come into contact with T.R.I. The test subjects inhaled the vapour of T.R.I. continuously for five hours in an exposure chamber in which the con- 
centration was maintained at a constant level ( $\pm 6 \%$ ) during the experiment. The concentrations of T.R.I. used in the individual tests were: $500,850,820,530 \mu \mathrm{g} . / 1$. In one experiment the same individual was exposed for three successive days to concentrations of 570,590 , and $440 \mu \mathrm{g} . / 1$. During the last two hours of the exposures the concentrations of T.R.I. in the expired air of the subjects were determined, and from these data and from the concentrations of T.R.I. in the inhaled air the quantity of T.R.I. retained by the exposed individual was calculated (Souček et al., 1952).

During the exposure period and the following three days all the urine was collected and analysed. In the later stages of desaturation 24-hour specimens of urine were analysed. The estimation of the metabolites was continued as long as the analytical methods permitted. In one subject the effect of administering intravenously $60 \mathrm{ml}$. of a $20 \%$ solution of glucose and 15 units of insulin at the end of the exposure was investigated. It is known that after administration of glucose with insulin the ethanol level in the blood diminishes more rapidly than under normal conditions. For this reason, it was of interest to find out whether glucose and insulin would also influence the rate of excretion of trichloroethanol, or perhaps the entire metabolism of T.R.I.

Determination of Monochloroacetic Acid.-Twenty-five millilitres of urine were acidified with $1 \mathrm{ml}$. of concentrated sulphuric acid and extracted five times with equal quantities of ethyl ether. The combined extracts were shaken with $1 \mathrm{ml}$. of pyridine, the ether evaporated under vacuum and the residue made up with water to $2.5 \mathrm{ml}$. From this concentrated extract a measured quantity was put on Whatman No. 4 chromatographic paper and developed descendingly by a $1: 1$ mixture of pyridine and amyl alcohol saturated with water. Simultaneously, a standard solution of monochloroacetic acid was subjected to the same chromatographic procedure. The position of the standard spot was detected with a solution of $0.1 \%$ methyl red in $60 \%$ ethanol adjusted to $p \mathrm{H} 6.5$ with a drop of $\mathrm{NaOH}$ solution; it appears as a pink stain on a yellow background. According to the position of the standard spot the appropriate area is cut out from the chromatogram, and the organically bound chlorine determined by the method of Judah (1949), modified by Vlachová (1955). The principle of the method is as follows. Organically bound chlorine is oxidized by heating with silver dichromate in concentrated sulphuric acid. The liberated chlorine is transferred by a stream of nitrogen into a solution of potassium iodide, where it liberates an equivalent quantity of iodine, which is estimated colorimetrically after adding a solution of starch. This method permits the determination of $3 \mu \mathrm{g}$. of chlorine with an accuracy of $97 \pm 6 \%$. It was possible to determine monochloroacetic acid in urine with an accuracy of 87 to $115 \%$, the minimum measurable amount being $30 \mu \mathrm{g}$.

Determination of Trichloroacetic Acid.-To $2 \mathrm{ml}$. of urine was added $8 \mathrm{ml}$. of pure pyridine and $5 \mathrm{ml}$. of a $20 \%$ solution of sodium hydroxide. The mixture was shaken, heated for 15 minutes in a water-bath at $70^{\circ} \mathrm{C}$. and then cooled in ice water; $7.5 \mathrm{ml}$. of the coloured pyridine layer was withdrawn with a pipette, clarified with $3 \mathrm{ml}$. of water and the extinction determined at a wavelength of $530 \mathrm{~m} \mu$ in a Coleman junior spectrophotometer. The accuracy of the determination is $97 \pm 5 \%$; the minimum measurable concentration is $2 \mu \mathrm{g}$. in $1 \mathrm{ml}$. of urine.

Determination of Trichloroethanol.-The modified method of Butler (1949) was employed. A $10 \mathrm{ml}$. sample of urine was acidified with $1 \mathrm{ml}$. of concentrated sulphuric acid and heated in a sealed tube for 14 hours in a waterbath at $90^{\circ} \mathrm{C}$. The tube was opened and to $2 \mathrm{ml}$. of the sample was added $0.5 \mathrm{~g}$. of an anion exchanger (OAL of the Stalin Works, Zaluzi near Most, Czechoslovakia) and the mixture shaken for $\mathbf{1 0}$ minutes. The trichloroacetic acid is quantitatively retained on the anion exchanger, while the trichloroethanol, liberated by the preceding hydrolysis from its linkage to glucuronic acid, remains in solution. To $\mathbf{0 . 2} \mathrm{ml}$. of the supernatant was added $0.8 \mathrm{ml}$. of an oxidizing mixture $\left(2 \mathrm{~g} . \mathrm{K}_{2} \mathrm{Cr}_{2} \mathrm{O}_{7}+\right.$ $70 \mathrm{ml}$. concentrated $\mathrm{H}_{2} \mathrm{SO}_{4}+30 \mathrm{ml} . \mathrm{H}_{2} \mathrm{O}$ ) and left for one hour at room temperature. Trichloroethanol is oxidized to trichloroacetic acid, which was estimated colorimetrically as above. The minimum measurable concentration is $10 \mu \mathrm{g}$. in $1 \mathrm{ml}$. of urine and the accuracy of the determination $92-102 \%$. The hydrolysis of trichloroethanol glucuronide is accompanied by some loss, so that only $70 \%$ of the total trichloroethanol can be determined. The values of trichloroethanol were therefore multiplied by the factor 1.43 .

Since this work was carried out, Vlachová (1957) has elaborated a new method for the determination of trichloroethanol in the presence of trichloroacetic acid, permitting the estimation of trichloroethanol in urine with an accuracy of $100 \pm 4.5 \%$, the limit of detectability being $1 \mu \mathrm{g}$.

\section{Results}

The test subjects retained 630-1,280 mg. (average $915 \mathrm{mg}$.) of T.R.I., representing $58-70 \%$ (average $64 \%$ ) of T.R.I. inhaled during exposure. The individual metabolites were excreted as follows:-

Monochloroacetic Acid.-This substance appears in the urine a few minutes after the beginning of the inhalation of T.R.I. vapour. The quantity in the urine increases rapidly, attaining a maximum immediately after the end of exposure, after which it falls exponentially. The total quantity excreted was $30-75 \mathrm{mg}$. (average $50 \mathrm{mg}$.) representing an average of $4 \%$ of the quantity of T.R.I. retained in the organism. The excretion continued for 48 to 168 hours (average 112 hours) after the end of the exposure. The half-period of excretion was about 15 hours. The course of excretion is shown in Fig. 1, curve 1.

Trichloroacetic Acid.-This acid appears in the urine immediately after the beginning of the inhalation of T.R.I. vapours and its concentration rises slowly; the maximum excretion was attained 


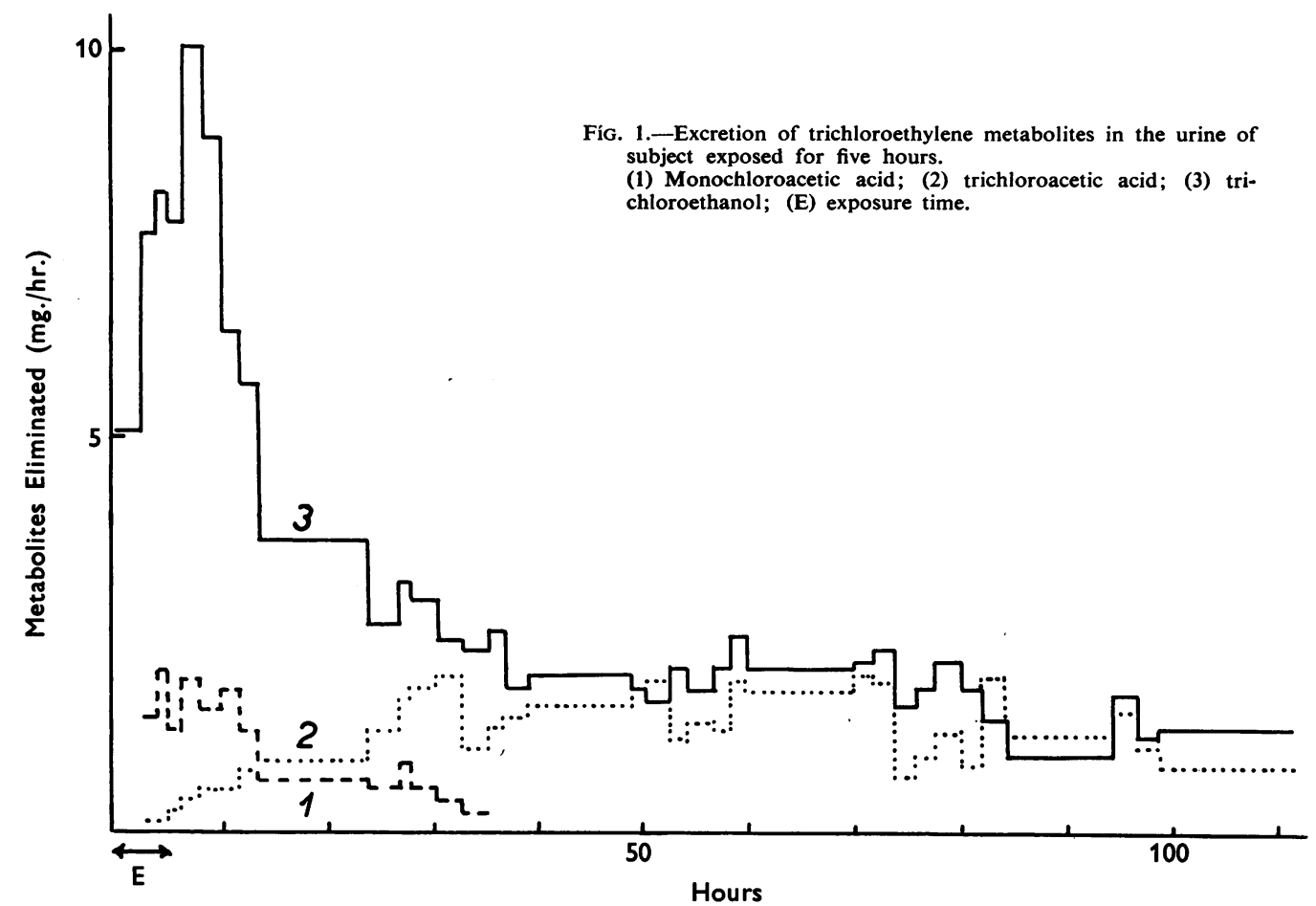

within 24 hours in four experiments and within 48 hours in three others. After attaining the maximum, the fall in the rate of excretion could be analysed into the sum of two exponential rates.

The total quantity excreted was $120-560 \mathrm{mg}$. (average 260 mg.) representing 10-30\% (average 19\%) of the quantity of T.R.I. retained. Excretion lasted 312 to 520 hours (average 387 hours). The average half-period of excretion was 50 hours in the first phase, which lasted about five days, and 70 hours in the second phase, which lasted about 14 days.

The curve 2 in Fig. 1 shows the course of excretion of T.C.A. in one of the experiments, where the three metabolites were determined in each portion of urine excreted over a period of 110 hours from the termination of exposure. A feature of the excretion of T.C.A. is the periodicity; the amount in the urine reaches a maximum at 1300 hours each day, falls and rises again. These changes in the concentration of T.C.A. were not connected with the urine flow which varied only quite insignificantly.

Trichloroethanol.-This metabolite also appears in the urine very soon after the beginning of the inhalation of T.R.I. vapour. The quantity excreted rises rapidly, attaining its maximum a few hours after the end of exposure; its concentration then falls exponentially as the sum of two rates, a fast

one at the beginning followed by a slower one.

The total quantity of T.C.E. excreted amounted to $415-655 \mathrm{mg}$. (average $520 \mathrm{mg}$.), representing $32-59 \%$ (average $50 \%$ ) of the quantity of T.R.I. retained. The metabolite was excreted for 312 to 390 hours (average 350 hours). The average halfperiod of excretion was 24 hours in the first phase, which lasted three to four days, and $\mathbf{4 0}$ hours in the second phase, which lasted seven to nine days.

The concentration of T.C.E. in the individual urine specimens did not exhibit such a remarkable fluctuation in the course of the day as the concentration of T.C.A. (Fig. 1, curve 3).

The total quantity of all three metabolites excreted in the urine amounted to 43-101\% (average $73 \%$ ) of T.R.I. retained in the organism. The individual metabolites representing M.C.A. $4 \%$, T.C.A. $19 \%$ and T.C.E. $50 \%$ give a ratio of approximately M.C.A. : T.C.A. : T.C.E. $=1: 5: 12$.

In one experiment, glucose administered with insulin exerted a distinct influence on the total quantities of the three metabolites excreted. One man was exposed for five hours to T.R.I. concentrations of 500 and $530 \mu \mathrm{g} . / 1$., respectively; the quantities of T.R.I. retained amounted to 770 and $860 \mathrm{mg}$. respectively and the percentage of each metabolite excreted was as follows: 


\begin{tabular}{c|l|c|c|c}
\hline Experiment & & $\begin{array}{c}\text { M.C.A. } \\
(\%)\end{array}$ & $\begin{array}{c}\text { T.C.A. } \\
(\%)\end{array}$ & $\begin{array}{c}\text { T.C.E. } \\
(\%)\end{array}$ \\
\hline 1 & $\begin{array}{l}\text { T.R.I. alone } \\
\text { T.R.l. followed by } \\
\text { glucose and insulin }\end{array}$ & 5 & 30 & 45 \\
\hline
\end{tabular}

The giving of glucose and insulin caused an overall increase of approximately $22 \%$ for all metabolites excreted. On the first day after exposure the quantity of T.C.E. excreted was 2.6 times that excreted on the first day after exposure to T.R.I. alone. The quantity of T.C.A. was not noticeably influenced on the first day of excretion nor was the total duration of excretion of the metabolites influenced by the administration of glucose with insulin.

\section{Discussion}

The quantity of T.C.A. excreted after exposure of our subjects to T.R.I. vapours is in agreement with the findings in our earlier work and with those of other authors mentioned in the introduction. Considerable individual fluctuations in the quantities of this metabolite excreted were again confirmed. The causes of the periodic fluctuations of the T.C.A. concentration in the individual specimen of urine passed in the course of the day cannot be explained but show the inappropriateness of judging the level of exposure to T.R.I. from the quantity of T.C.A. found in an arbitrary sample of urine. For this purpose it is always necessary to analyse the total urine excreted during 24 hours in order to obtain significant results.

These experiments have again confirmed that the total quantity of T.C.E. excreted by man is approximately double that of T.C.A. This ratio applies to the total quantity of both metabolites excreted after a given exposure to vapours of T.R.I. This ratio, however, cannot be judged from the quantities found in single arbitrary samples of urine.

Monochloroacetic acid is only formed in quantities much lower than those of T.C.A. and T.C.E. Since M.C.A., however, is unquestionably the most toxic of the metabolites hitherto investigated, a certain significance could be ascribed to it in the overall toxicity of T.R.I.

According to Marhold (1953), the L.D.50 of some metabolites of T.R.I. for white mice when compared with that of sodium acetate are as follows:

\begin{tabular}{l|l|l}
\hline & & L.D.50 (g./kg.) \\
\hline Sodium monochloroacetate & & $0.109 \pm 0.050$ \\
Trichloroethanol & & $0.201 \pm 0.012$ \\
Sodium acetate & $0.404 \pm 0.015$ \\
Sodium trichloroacetate & $2.37 \pm 0.11$ \\
\hline
\end{tabular}

The excretion of monochloroacetic acid from the organism proceeds fastest, that of trichloroethanol more slowly, and that of trichloroacetic acid is slower still. The half-periods of excretion (in hours) are approximately as follows:

\begin{tabular}{l|c|c|c}
\hline & M.C.A. & T.C.E. & T.C.A. \\
\hline First phase & 15 & 24 & 50 \\
Second phase & - & 40 & 70 \\
\hline
\end{tabular}

These rates of excretion seem to be comparatively constant. The slow excretion of T.C.A. is generally known for both man and various animals. The average excretion time of T.C.E. has been found to be 24 hours ( 20 to 29 hours). The data of Přerovská, Srbová, and Stýblová (1958), who investigated the excretion of T.C.E. after administration of T.R.I. by mouth, suggests a half-period of 28 hours; Bartoníček and Souček (1959), experimenting on rabbits, found an average half-period of 20 hours (14 to 26 hours).

Excretion and formation of T.R.I. metabolites can be influenced by drugs. According to Forssman, Owe-Larsson, and Skog (1955), the excretion of T.C.A., after giving T.R.I. to dogs and rats, drops practically to zero after administration of tetraethylthiuram disulphide (T.E.T.D._-“antabuse"). It is known that T.E.T.D. inhibits the oxidation to acetic acid of acetaldehyde in the organism. The finding of Forssman et al. could therefore be explained by assuming an inhibition of oxidation processes by which T.C.A. is formed from one of its possible precursors such as trichloroethanol or chloral, which in turn are formed in the organism from T.R.I. Administration of glucose with insulin, on the other hand, increases the quantity of excreted metabolites and thus influences the metabolism of T.R.I. in a positive sense. These findings could perhaps be utilized to influence the toxicity of T.R.I. or to influence the course of poisoning by this substance. Further research must decide whether inhibition or acceleration of the oxidation of T.R.I. or of its metabolites would be better suited for this purpose.

\section{REFERENCES}

Ahlmark, A., and Forssman, S. (1949). Proc. IX. Int. Congr. Industr. Med., London, 1948, p. 552.

, (1951). Acta physiol. scand., 22.326.

Bardodexj, Z., and Krivucová, M. (1958). Csl. Hyg., 3, 268.

Barrett, H. M., and Johnston, J. H. (1939). J. biol. Chem., 127, 765.

, Cunningham, J. C., and Johnston, J. H. (1939). J. industr. Hyg., 21, 479.

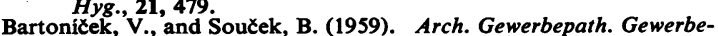
hyg., 17, 283.

Butler, T. C. (1949). J. Pharm. exp. Ther., 95, 84.

Fabre, R. (1949). Proc. IX. Int. Congr. Industr. Med., London, 1948, p. 546

For, and Truhaut, R. (1952). Brit. J. industr. Med., 9, 39.

Forssman, S. (1945). Svenska Läk.-Tidn., 42, 1964. 
Forssman, S. and Holmquist, C. E. (1953). Acta. pharmacol. $(K b h$,$) 9,235.$

Owe-Larsson, A.. and Skog, E. (1955). Arch. Gewerbepath. Gewerbehyg., 13, 619.

Grandjean, E., Münchinger, R., Turrian, V., Haas, P. A., Knoepfel,

H. K., and Rosenmund, H. (1955), Brit. J. industr. Med., 12, 131

Judah, J. D. (1949). Biochem. J., 45, 60.

Marhold, J. (1953). Laborat. zpráva VUOS, Pardubice-Rybitví.

Powell, J. F. (1945). Brit. J. industr. Med., 2, 142.
Přerovská, I. Srbová J., and Stýblová, V. (1958). Pracov. Lék.. 10,417 .

Soucek, B. (1954). Ibid., 6, 277.

- (1955). Ibid., 7, 89. , and Pavelková, E. (1953). Ibid., 5, 62. and Vlachová, D. (1954). Ibid., 6, 330. Teisinger, J., and Pavelková, E. (1952). Ibid., 4, 31 Teisinger, J.. Stýblová, V., and Vlachová, D. (1955). Ibid. 7, 258. Vlachová, D. (1955). Ibid., 7, 98.

(1957). J. Hyg. Epid. Microbiol. Immunol., 1, 225.

\section{THE OCTOBER (1959) ISSUE}

The October (1959) issue contains the following papers:-

Population Studies of Chronic Respiratory Disease: A Comparison of Miners, Foundryworkers, and Others in

Staveley, Derbyshire. By I. T. T. Higgins, A. L. Cochrane, J. C. Gilson, and C. H. Wood.

Sickness Absence Among Railway Clerical Staff. By Derek S. Pugh, Cecil Gordon, and Katherine Lévy.

Pneumoconiosis in Carbon Electrode Makers. By A. J. Watson, J. Black, A. T. Doig, and G. Nagelschmidt.

The Effect of Different Concentrations of Silicic Acid and Silica Dust on the Biosynthesis of Collagen in Tissue Cultures. By M. Chvapil and D. Holečková.

Studies on the Nature and Aetiology of Respiratory Disability in Witwatersrand Gold-miners Free of Radiological Silicosis. By Margaret R. Becklake, Saul Zwi, and W. Lutz.

An Analysis of Some Observations of Thermal Comfort in an Equatorial Climate. By C. G. Webb.

Late Consequences of the Neurological Forms of Decompression Sickness. By I. Rózsahegyi.

Lung Cancer in Coal-miners. By R. Abbey Smith.

The Origin of the Term Anthracosis. By A. Meiklejohn.

Miscellanea:

A Laboratory Trial of Some Modern Screening Tests for the Detection of Glucose and Protein in Urine. By L. H. Turnbull.

Obituaries:

Mr. A. Treve Holman.

Dr. Lasar Dunner.

Book Reviews.

Index to Volume 16.

A number of copies are still available and may be obtained from the Publishing Manager, British Medical Association, Tavistock Square, W.C.1, price 17s. $6 d$. 